\title{
СОВЕРШЕНСТВОВАНИЕ МЕТОДИЧЕСКИХ ПОДХОДОВ, ТЕХНИЧЕСКИХ РЕШЕНИЙ И ОБЕСПЕЧЕНИЕ ДОСТУПНОСТИ ИНФОРМАЦИИ ПРИ УСТАНОВЛЕНИИ ВОДООХРАННЫХ ЗОН ВОДНЫХ ОБЪЕКТОВ
}

\author{
Л. Н. Гертман ${ }^{1}$, Е. В. Левачёв ${ }^{2}$, А. Н. Глинская ${ }^{3}$, \\ И. Ю. Буко , В. Д. Бладыко \\ ${ }^{1}$ Начальник отдела гидрологии и водоохранных территорий \\ 2 Магистр географических наук, младший научный сотрудник \\ ${ }^{3}$ Магистр технических наук, научный сотрудник \\ ${ }^{4}$ Научный сотрудник \\ ${ }^{5}$ Младший научный сотрудник \\ ${ }^{6}$ Младший научный сотрудник; Республиканское унитарное предприятие «Центральный научно-исследовательский институт \\ комплексного использования водных ресурсов» (РУП «ЦНИИКИВР»), Минск, Республика Беларусь, e-mail: mail@cricuwr.by
}

\begin{abstract}
Ресрерат
С целью повышения внимания и развития гражданской ответственности за окружающую среду на базе РУП «ЦНИИКИВР» создается каталог водоохранных зон и прибрежных полос водных объектов. Каталог позволяет получать информацию о границах водоохранных территорий для необходимой местности, дает возможность оперативно корректировать и даже определять направление хозяйственной деятельности с целью минимизации негативного воздействия на поверхностные водные объекты.
\end{abstract}

Ключевые слова: водоохранная зона, прибрежная полоса, защита окружающей среды.

\section{IMPROVEMENT OF METHODOLOGICAL APPROACHES, TECHNICAL SOLUTIONS AND ENSURING ACCESSIBILITY OF INFORMATION WHEN ESTABLISHING WATER PROTECTION ZONES OF WATER BODY}

Abstract

\author{
L. N. Hertman'1, Y. V. Levachou², A. N. Hlinskaya ${ }^{3}$, I. Yu. Buka ${ }^{4}$, V. D. Bladyka 5 , A. Z. Makus ${ }^{6}$
}

In order to increase attention and develop civil responsibility for the environment protection in the RUE "CRICUWR" a catalog of water protection zones of water bodies is being created. The catalog allows you to receive information about the boundaries of water protection areas for the required area, makes it possible to promptly correct and even determine the direction of economic activity in order to minimize the negative impact on surface water bodies.

Key words: water protection zone, coastal strip, environmental protection.

\section{Введение}

В 2015 году вступил в действие Водный кодекс Республики Беларусь (далее - Кодекс), содержащий новые требования к водоохранным зонам (далее - В3), прибрежным полосам (далее - ПП) водных объектов (далее - ВО), включая разработку проектов и режим осуществления хозяйственной и иной деятельности в пределах этих территорий. Согласно пункту 8 статьи 63 Кодекса проекты В3 и ПП, утвержденные до вступления в силу Кодекса, должны быть приведены в соответствие с требованиями статьи 52 [1].

Основная задача В3 и ПП заключается в предотвращении загрязнения и засорения поверхностных водных объектов путем установления на территории, прилегающей к водному объекту, особого режима осуществления хозяйственной и иной деятельности. Правовое регулирование ведения хозяйственной деятельности в границах водоохранных зон осуществляется в соответствии с положениями главы 11 Кодекса [1].

В Республике Беларусь в соответствии с требованиями ст. 63 Кодекса проведены работы по разработке и корректировке проектов В3 и ПП водных объектов административных районов. Границы В3 и ПП устанавливаются местными исполнительными и распорядительными органами в составе проектов ВЗ и ПП, а в случае их отсутствия - отдельно.

В РУП «ЦНИИКИВР» накоплен значительный опыт разработки проектов В3 и ПП ВО. Наиболее трудоемкими и сложными являются работы по разработке и корректировке В3 и ПП для ВО административных районов в целом.

С целью расширения доступности информации, привлечения внимания и развития гражданской ответственности за рациональное природопользование РУП «ЦНИИКИВР» создается каталог ВЗ и ПП ВО (далее - Каталог). Создание Каталога направлено, в том числе, на обеспечение открытого доступа к экологической информации, имеющейся в распоряжении государственных органов, что соответствует нормам ратифицированной Беларусью Орхусской конвенции а также статье 46 Конституции Республики Беларусь. Информация Каталога позволяет для выбранной территории оперативно получить представление о наличии ограничений для определенных видов хозяйственной деятельности в границах В3 и ПП. Это даёт возможность скорректировать и даже заранее определить направление хозяйственной деятельности на рассматриваемой территории с целью минимизации воздействия на поверхностные ВО.

\section{Установление водоохранных зон}

Разработка проектов ВЗ и ПП ВО на территории Республики Беларусь проводилась, начиная с 80-х гг., на различных правовых, методических и организационных принципах.

Так, изначально разработка проектов В3 и ПП для малых рек осуществлялась на основании постановлений Совета Министров БССР «Об усилении охраны малых рек от загрязнения, засорения и истощения и о рациональном использовании их водных ресурсов» от 11.12.1980 № 415 и «Об улучшении организации работ по охране малых рек от загрязнения, засорения и истощения» от 21.03.1986 № 86. Методической основой выделения границ В3 и ПП в этот период служило Положение о водоохранных полосах (зонах) малых рек Белорусской ССР, утвержденное постановлением Совета Министров БССР от 18.01.1983 № 18. За картографическую основу были приняты топокарты М 1:10 000.

Проекты В3 и ПП малых рек и впадающих в них ручьев были разработаны Белорусским республиканским проектным институтом 
Вестник Брестского государственного технического университета. 2021

по землеустройству «Белгипрозем» и его областными филиалами. На малых реках, озерах, прудах и водохранилищах ширина В3 принималась в основном равной 500 м от среднемноголетнего меженного уровня воды, а ширина ПП устанавливалась от 30 до $100 \mathrm{M}$.

Проекты В3 и ПП больших и средних рек разрабатывались РУП «ЦНИИКИВР» на основании постановлений Совета Министров Республики Беларусь «Об утверждении Положения о водоохранных зонах и прибрежных полосах больших и средних рек» от 05.03.2002 № 297 и «Об утверждении Положения о порядке установления размеров и границ водоохранных зон и прибрежных полос водных объектов и режиме ведения в них хозяйственной и иной деятельности и признании утратившими силу некоторых постановлений Совета Министров Республики Беларусь» от 21.03.2006 № 377. Методической основой выделения границ В3 и ПП в этот период служило постановление Министерства природных ресурсов и охраны окружающей среды Республики Беларусь «О требованиях к разработке проектов водоохранных зон и прибрежных полос водных объектов» от 29.10.2007 № 78. Данные проекты В3 и ПП были разработаны на картах масштаба 1:50 000 и 1:10 000.

В ходе практического использования проектов выявился ряд недостатков принципиального значения в установлении границ В3 и ПП ВО, вступающих в противоречие с современным законодательством и средствами обработки и хранения информации.

Ранее установленные границы В3 и ПП наносились отдельно на картографические материалы земель различных категорий картосхемы земель лесного фонда, земель сельскохозяйственного назначения, земель населенных пунктов, садоводческих товариществ и дачных кооперативов и хранились порознь в соответствующих ведомствах, что создавало трудности в их использовании.

Для некоторых водных объектов Республики Беларусь в пределах населенных пунктов границы ПП не разрабатывались, либо наносились по урезу воды водных объектов. Зачастую границы ПП водных объектов нанесены без учета существовавшей застройки.

В настоящее время при разработке проекта В3 и ПП руководящими документами являются:

- Водный кодекс Республики Беларусь от 30 апреля 2014 г. № 149-3 [1];

- постановление Министерства природных ресурсов и охрань окружающей среды Республики Беларусь 4 мая 2015 г. № 18 «О требованиях к разработке проектов водо-охранных зон и прибрежных полос» (с изменениями от 17 марта 2017 г. № 9) [9];

- ЭкоНиП 17.01.06-001-2017 Охрана окружающей среды и природопользование. Требования экологической безопасности [11].

Проекты В3 и ПП могут разрабатываться как для административных районов и отдельных населённых пунктов, так и для отдельных ВО и их участков.

Проекты ВЗ и ПП ВО яВляются объектом государственной экологической экспертизы в соответствии с Законом Республики Беларусь 18 июля 2016 г. № 399-3 «О государственной экологической экспертизе, стратегической экологической оценке и оценке воздействия на окружающую среду» [8], а также объектом юридической экспертизы в составе решения местных исполнительных и распорядительных органов власти, как технический нормативный правовой акт, не относящийся к области технического нормирования и стандартизации (Закон Республики Беларусь «О нормативных правовых актах» от 17 июля 2018 г. № 130-3) [7].

Основным назначением В3 и ПП ВО является предотвращение загрязнения, засорения и истощения водных объектов, сохранение среды обитания объектов животного и произрастания растительного мира. В этих целях при установлении размеров границ водоохранных территорий определяются источники, хозяйственная и иная деятельность которых может оказывать отрицательное воздействие на экологическое состояние, как непосредственно ВО, так и прилегающей к ним территории. Размещение и функционирование в пределах водоохранных территорий хозяйствующих субъектов требует разработки и выполнения определенных экологических условий, обеспечивающих защиту окружающей среды от загрязнения. Данные экологические условия должны учитываться при разработке проектов строительства и эксплуатации хозяйственных объектов.

Параметры В3 и ПП устанавливаются с учетом существующих природных условий, в том числе рельефа местности, вида земель в зависимости от классификации поверхностных водных объектов и протяженности рек на основании статьи 52 Кодекса. Параметром, характеризующим В3 и ПП, является их ширина. Статьи 53 и 54 Кодекса регулируют режим осуществления хозяйственной деятельности в пределах водоохранных территорий.

Разработка проектов В3 и ПП предусматривает следующие виды работ:

1. подготовительные:

- подбор и приобретение необходимых планово-картографических материалов:

- сбор и систематизацию данных о гидрологических характеристиках поверхностного водного объекта, речном стоке, площади (в том числе водосборной) и протяженности поверхностного водного объекта, его целевом использовании, источниках загрязнения поверхностных вод, а также сведений и материалов, характеризующих существующие природные условия и характер землепользования, в том числе рельеф местности и функциональное назначение земель;

- анализ функционального использования исследуемой территории, определение уровня инженерно-технической инфраструктуры исследуемой территории;

2. полевые:

- уточнение на местности природных условий;

- обследование объектов, которые могут оказывать вредное воздействие на поверхностный водный объект;

3. камеральные:

- анализ и обобщение результатов полевых работ;

- составление перечня точечных и диффузных источников загрязнения поверхностного водного объекта с проведением анализа уровня антропогенного воздействия и характера землепользования исследуемой территории;

- нанесение на планово-картографические материалы буферных зон, соответствующих размерам В3 и ПП, источников загрязнения и информационных знаков;

- подготовку обоснования по устанавливаемым границам В3 и ПП;

- разработку мероприятий, направленных на сохранение и восстановление поверхностного водного объекта.

На первом этапе разработки проекта важным условием является подбор актуальных планово-картографических материалов. В соответствии с требованиями постановления Минприроды от 04.05.2015 № 18 границы В3 и ПП наносятся на планово-картографические материалы с применением ГИС-технологий. Границы В3 для межселенных территорий, а также границы В3 в населенных пунктах наносятся на планово-картографические материалы масштаба 1:10000. Границы ПП в городах и поселках городского типа наносятся на планово-картографические материалы масштаба 1:2000 [5].

Для разработки проектов В3 и ПП, как правило, используется земельно-информационная система (далее - ЗИС). База геоданных ЗИС Республики Беларусь содержит информацию о земельных участках, их границах и административно-территориальной принадлежности, распределении земель по категориям и видам прав на землю, землевладельцах и землепользователях, видах земель, ограничениях землепользования, текущих изменениях в составе и распределении земель, а также элементы топографического содержания [5]. Пространственные слои базы геоданных ЗИС объединены в ряд групп слоев, из которых для разработки проектов В3 и ПП непосредственно используются следующие слои: Admi - объекты административно-территориального и территориального деления; Lots - поворотные точки, границы и собственно земельные участки собственников, владельцев, пользователей, арендаторов; Land - контуры земель (рисунок 1). 


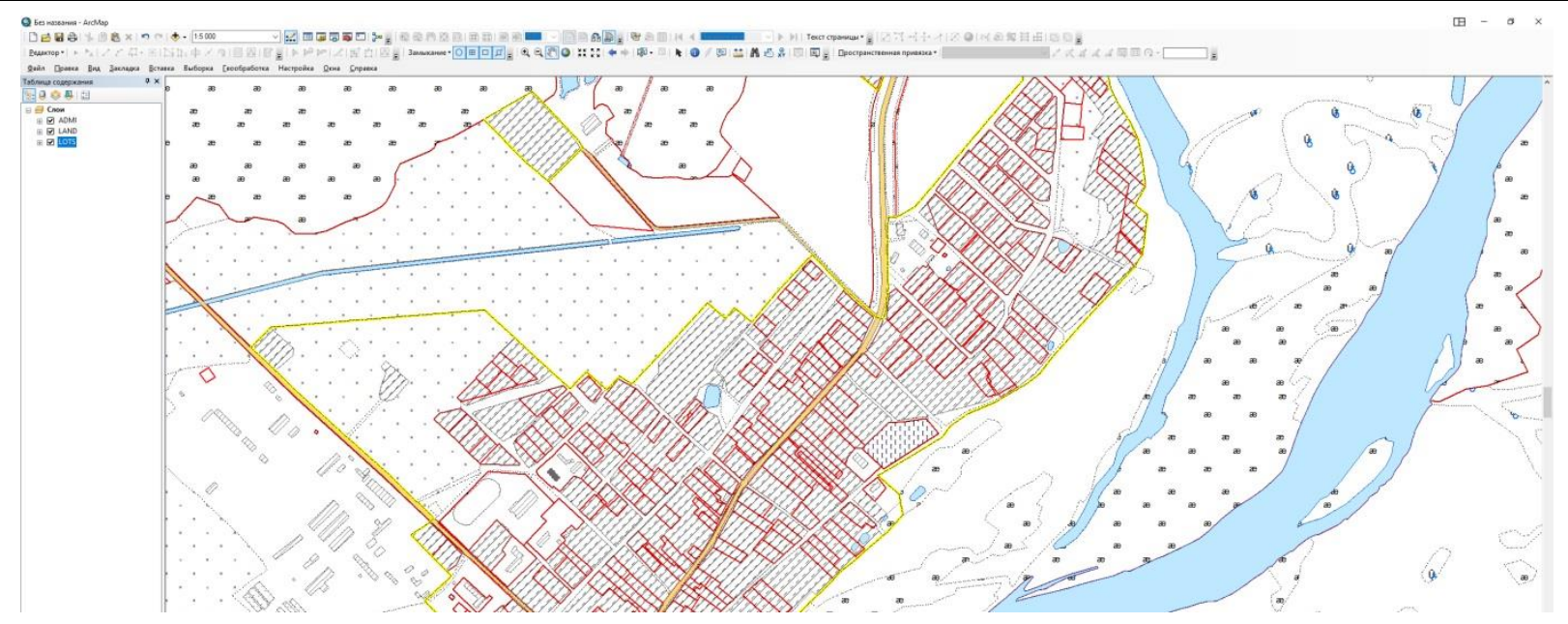

Рисунок 1 - Пространственные слои ADMI, LAND, LOTS базы геоданных ЗИС

Важным элементом на первом этапе работ является классификация ВО в соответствии со статьей 5 Кодекса, что дает основание для установления минимальных размеров границ В3 и ПП. Для этого проводится анализ литературных данных, данных инвентаризации ВО, выполненной РУП ЦНИИКИВР в 2016-2020 гг., и доступных картографических материалов различных лет съемки с наложением на современные условия.

На подготовительном этапе также важным являются сбор и систематизация данных о поверхностных ВО, а также о существующих природных условиях и характере землепользования.

При разработке проектов В3 и ПП ВО границы должны устанавливаться на основании всестороннего анализа природных условий водосборной территории, в частности, рельефа местности, климатических, почвенных, гидрогеологических условий, соотношения различных видов землепользования (вида земель, функционального использования территории) и прочих природных и антропогенных факторов и условий согласно пункту 1 статьи 52 Кодекса.

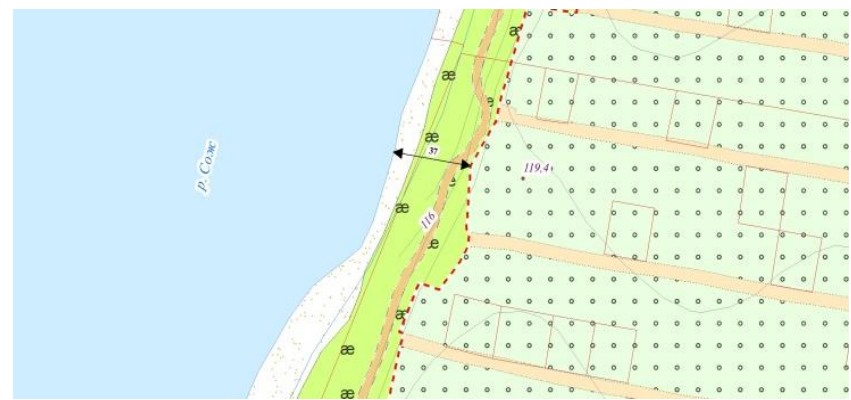

Рисунок 2 - Цифровая модель рельефа, наложенная на ЗИС

В населенных пунктах дополнительно ширина В3 и ПП устанавливается исходя из утвержденной градостроительной документации с учетом существующей застройки, системы инженерного обеспечения и благоустройства.

Работы предусматривают проведение анализа литературных источников по описанию гидрологических характеристик водных объектов, климатических, гидрологических, гидрогеологических и других природных особенностей территории, имеющихся проектов ВЗ и ПП, различной кадастровой инфрормации, схем комплексной территориальной организации регионов, проектов детального планирования, генплана.

Анализ функционального использования исследуемой территории позволяет определить потенциальные источники негативного воздействия на ВО - точечные и диффузные.

На этапе полевых исследований проводится уточнение на местности природных условий: основных элементов рельефа, прилегающего к поверхностному водному объекту, состояния и характера использования земель, определение эрозионно опасных участков, а также видов земель, в том числе находящихся под застройкой, c нанесением на планово-картографические материалы участков, подлежащих залужению, посеву и посадке водохозяйственных лесонасаждений, рекультивации нарушенных земель.

В населенных пунктах особое внимание уделяется элементам благоустройства территории, в частности состоянию систем инженерного обеспечения и благоустройства в соответствии с требованиями постановления Совета Министров Республики Беларусь от 28.11.2012 № 1087 «Об утверждении Правил благоустройства и содержания населенных пунктов» [6].

Обследование объектов, которые могут оказывать вредное воздействие на поверхностный ВО, проводится с целью определения условий их дальнейшей эксплуатации или выноса за пределы В3 и ПП с учетом требований действующего законодательства.

Анализ и обобщение результатов подготовительных и полевых работ включает нанесение на планово-картографичческие материалы С применением ГИС-технологий границ ВЗ и ПП, подготовку обоснования по размерам границ и разработку мероприятий, направленных на сохранение и восстановление поверхностного водного объекта (рисунок 2, 3).

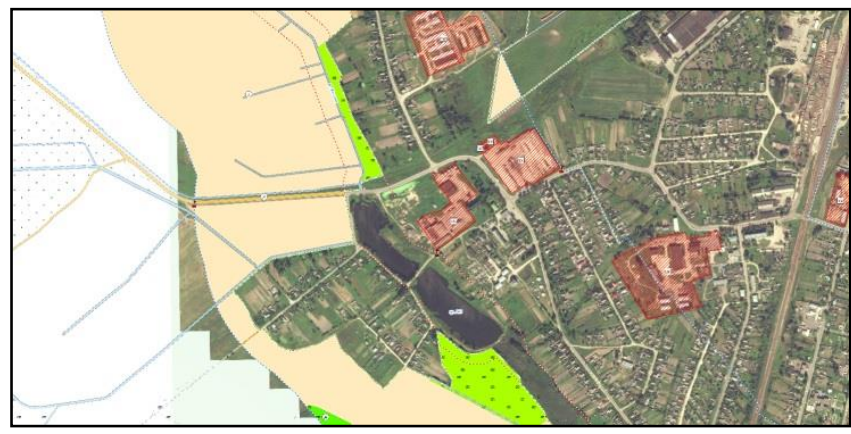

Рисунок 3 - Наложение современного космического снимка на ЗИС с нанесенными границами В3 и ПП, источниками загрязнения и информационными знаками

Обоснование размеров границ ВЗ и ПП базируется на оценке возможной степени антропогенного воздействия с учетом соотношения природных условий и существующей антропогенной нагрузки.

Для того чтобы В3 выполняли свою защитную функцию, установление размеров границ осуществляется на основе расчетов возможного выноса загрязняющих веществ с водосбора. Например, с целью математического подтверждения установления размеров границы В3 и ПП осуществляется расчет параметров по отдельным профилям на основе эмпирической зависимости, учитывающей геоморфологические особенности водосборной территории (рельефа и почвенного покрова), характер подстилающей поверхности, интенсивность осадков. 
Вестник Брестского государственного технического университета. 2021

Размеры В3 и ПП должны быть научно обоснованы, что позволяет, с одной стороны, обеспечить выполнение основных принципов охраны и использования вод, заложенных в Кодексе, - обеспечение рационального (устойчивого) водопользования, предупреждение загрязнения, засорения вод, а с другой стороны - вести экономически эффективную хозяйственную деятельность без дополнительных необоснованных ограничений.

Для объектов, расположенных в пределах В3, разрабатываются мероприятия, направленные на сохранение и восстановление поверхностного водного объекта с учетом действующих нормативных правовых актов и технических нормативных правовых актов, современных технологий и наилучших доступных технических методов.

Комплексный подход при разработке проектов ВЗ и ПП с использованием геоинформационных технологий положительно зарекомендовал себя на практике как удачное сочетание соблюдения экологических и экономических интересов в установлении размеров границ В3 и ПП, а также реализующий основную цель В3 и ПП, заключающуюся в предотвращении загрязнения и засорения поверхностных BO.

\section{Разработка и ведение Каталога}

С целью обеспечения открытого доступа к экологической информации, имеющейся в распоряжении государственных органов, в рамках выполнения задания 2.1.3 «Разработать каталог водоохранных территорий водных объектов в разрезе административных районов и бассейнов основных рек Республики Беларусь» ГНТП «Природопользование и экологические риски», 2016-2020 годы, осуществлялась разработка обобщенного каталога В3 и ПП.

Каталог является одним из компонентов разрабатываемой в РУП «ЦНИИКИВР» информационной системы «Государственный водный кадастр» (рисунок 4).

При разработке Каталога с обеспечением открытого доступа к информации в глобальной компьютерной сети Интернет использован язык программирования Python и Django - свободный программный каркас для веб-приложений на языке Python, использующий шаблон проектирования MVC. Проект поддерживается организацией Django Software Foundation.
Работа по наполнению Каталога включает на три этапа: подготовительный, основной и коррекционный.

Подготовительный этап наполнения Каталога включает в себя сбор и организацию базы данных проектов, имеющих положительное заключение Государственной экологической экспертизы. Экспортируется информация о ВО, возможных источниках загрязнения и рекомендациях по ведению хозяйственной деятельности и мероприятиях по предотвращению загрязнения ВО. Ввиду того, что картографической основой для каталога является общедоступная онлайн-карта OpenStreetMap, производится изменение проекции геоданных из CK63 в WGS-84 (рисунок 6). Также для объектов хозяйственной деятельности производится преобразование полигона в точку. В шейп-файлах В3 и ПП добавляются значения поля Id, по которому потом будет проведена привязка с уникальным номером проекта на сайте.

Таким образом, в результате работ подготовительного этапа создается 4 шейп-файла: В3, ПП, объектов хозяйственной деятельности в полигонах, объектов хозяйственной деятельности в точках; а также выписка из пояснительной записки об источниках загрязнения и рекомендациях к их хозяйственной деятельности. Далее шейпфайлы загружаются на сайт.

Основной этап создания Каталога состоит во введении на сайт информации о названии ВО и принадлежности ВЗ и ПП к ним. Для объектов хозяйственной деятельности вводится номер на картографическом материале, наименование, местоположение, функциональное назначение, наименование землепользователя, краткая характеристика объекта и соответствие режиму осуществления хозяйственной деятельности, также вводятся рекомендуемые мероприятия и сроки их проведения (рисунок 5).

После заполнения всех полей на сайте происходит их связывание в единый проект с возможностью его просмотра. Итогом основного этапа является ГИС-проект на сайте (рисунок 6), а также таблицы состава рекомендуемых мероприятий, характеристики объектов и соотношения площадей по функциональному использованию (рисунок 7).

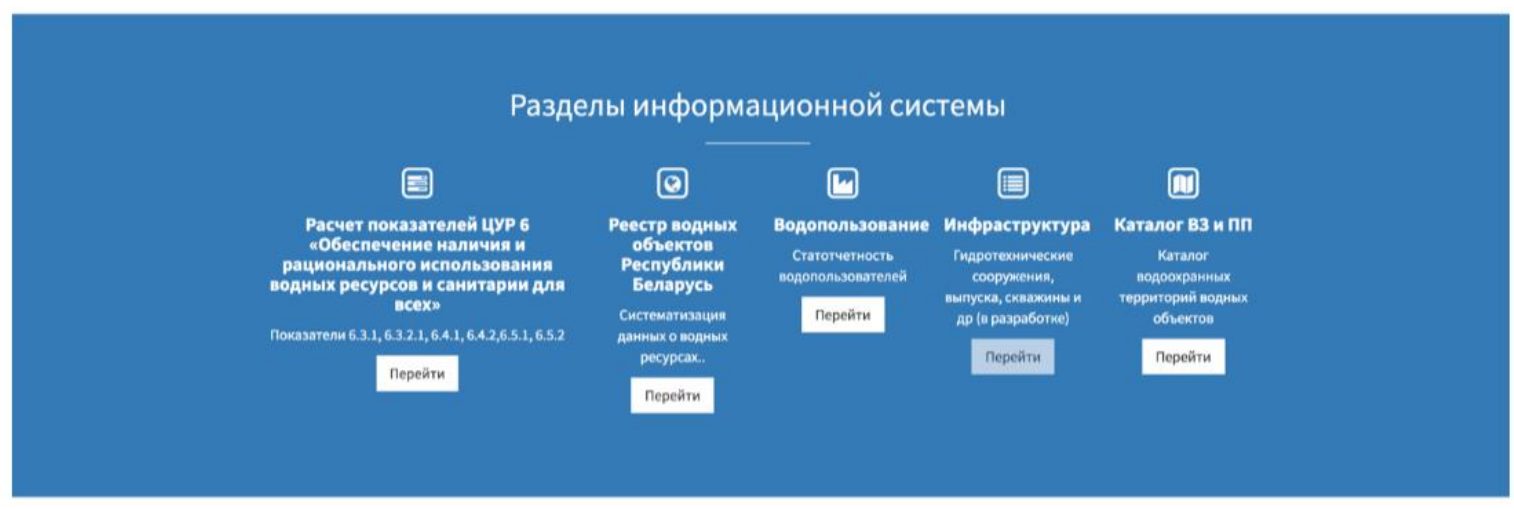

Рисунок 4 - Структура информационной системы Государственного водного кадастра

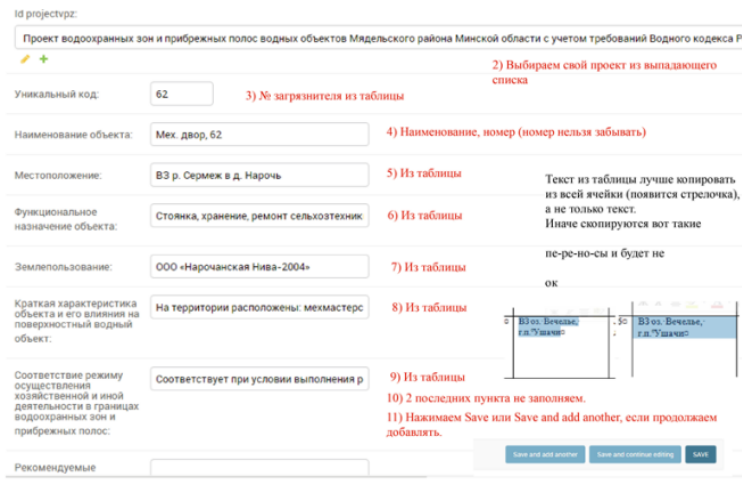

Рисунок 5 - Интерфейс редактирования данных обобщённого каталога и инструкция по их заполнению 


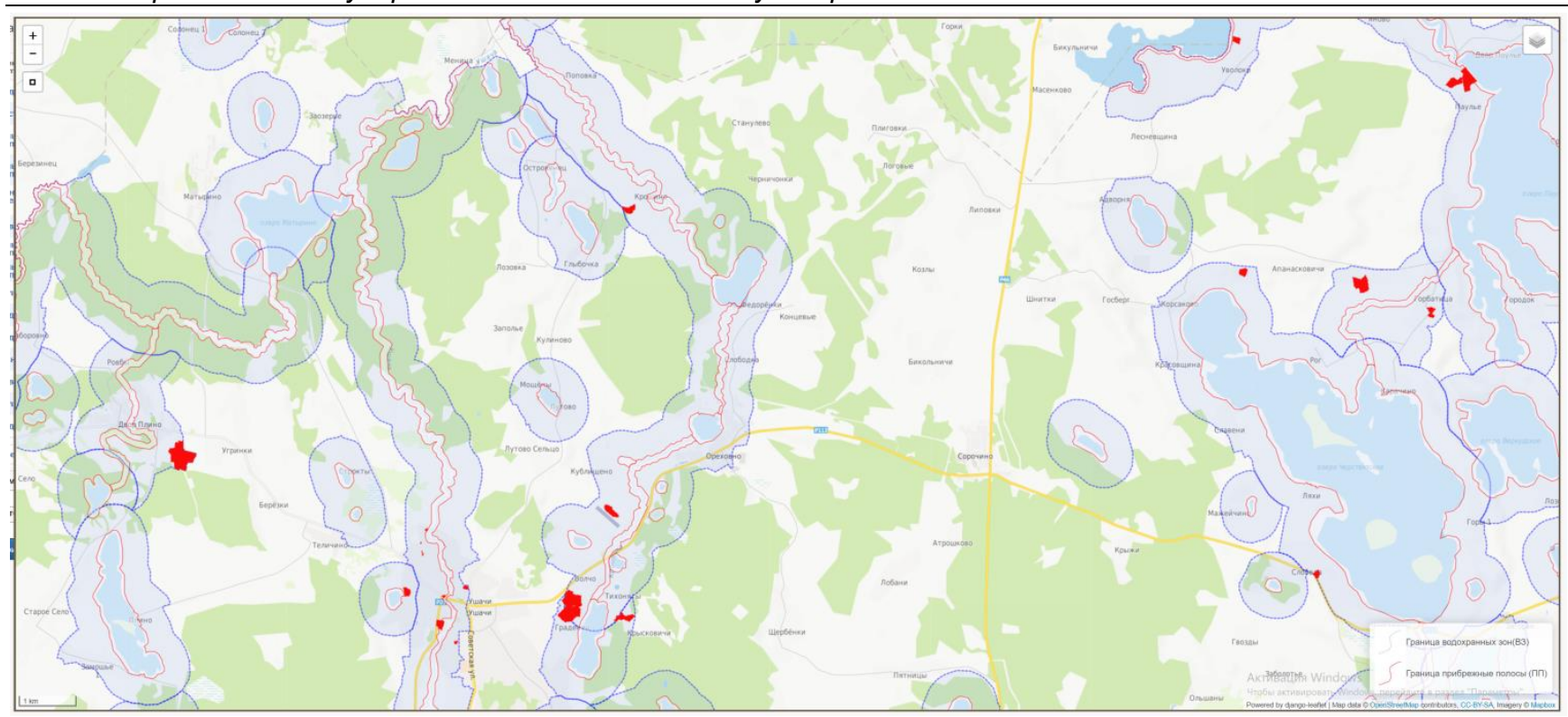

Рисунок 6 - Границы В3 и ПП Ушачского района

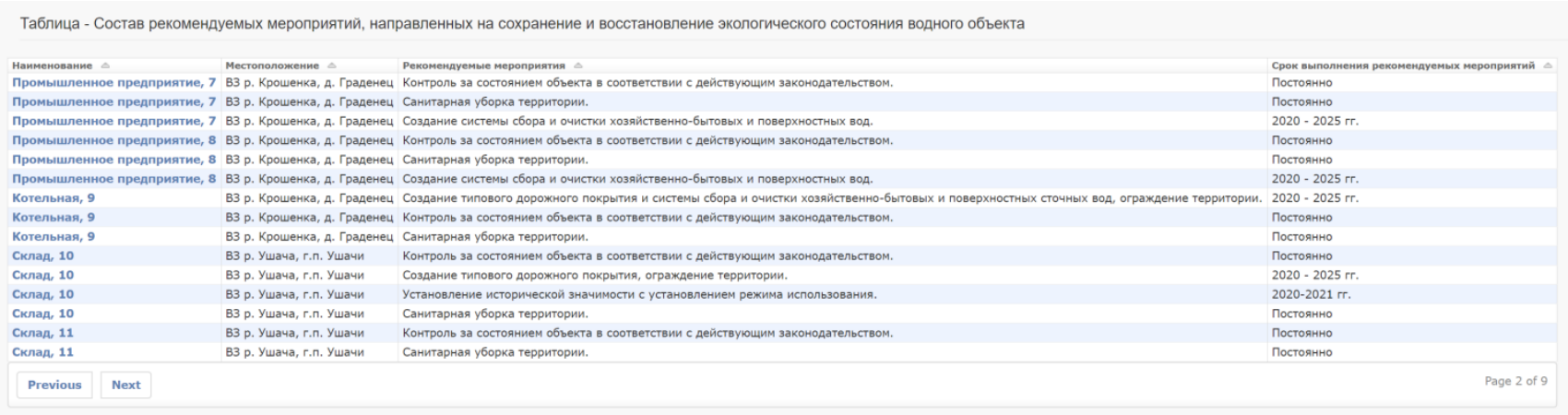

Рисунок 7 - Состав рекомендуемых мероприятий Ушачского района

Заключительным этапом создания Каталога является коррекционный. Он предусматривает дополнительную проверку работы сайта, так как при ручном вводе могут возникнуть ошибки и неточности. Например, если номер проекта указан неверно, от этого теряется работа всего проекта. После корректировки и устранения ошибок данные Каталога становятся доступны на сайте.

Доступ к данным Каталога разделён на два уровня: общедоступная и служебная информация. Общедоступная информация доступна для всех пользователей сети Интернет на сайте www.cricuwr.by в разделе Государственный водный кадастр и возможна для просмотра после утверждения проекта. Этот режим доступа позволяет увидеть информацию о географии В3. Служебный доступ даёт информацию не только о В3, но и о прибрежных полосах, потенциальных источниках загрязнения водных объектах, их расположении и рекомендациях по их хозяйственному использованию, структурном соотношении площадей в В3 и ПП. Такой уровень доступа предоставлен комитетам и инспекциям природных ресурсов и охраны окружающей среды.

\section{Заключение}

С целью защиты ресурсов поверхностных вод от загрязнения и засорения в Республике Беларусь разработаны проекты В3 и ПП ВО в разрезе административных единиц, а также отдельных ВО. Охрана поверхностных водных объектов осуществляется путем установления на территории, прилегающей к водному объекту, особого режима осуществления хозяйственной и иной деятельности.

В соответствии с требованиями Кодекса все административные единицы в Республике Беларусь имеют разработанный и прошедший государственную экологическую экспертизу проект
В3 и ПП водных объектов. Для систематизации и обеспечения доступности информации по проектам РУП «ЦНИИКИВР» разработал каталог В3 и ПП, который размещен на сайте института.

Наполнение Каталога В3 и ПП ВО - целостный законченный процесс отбора, оптимизации и предоставления информации об охране поверхностных водных объектов путем установления режима хозяйственной деятельности на водосборе. Каталог позволит оперативно предоставлять информацию о границах В3 и ПП ВО, а также скорректировать и даже определить направление хозяйственной деятельности с целью минимизации воздействия на поверхностные BO.

В настоящее время Каталог включает материалы проектов В3 и ПП ВО более 50 административных районов и постоянно дополняется новой информацией из проектов, прошедших государственную экологическую экспертизу. Каталог имеет два уровня доступа: общедоступная и служебная информация. В подразделе «Общедоступная информация» приводится общая информация (название водного объекта, местоположение, разработчик и др. сведения) об утвержденных проектах В3 и ПП. В подразделе "Служебная информация» приводятся данные об объектах-загрязнителях, мероприятиях, а также информация о структурном соотношении площадей в В3 и ПП.

\section{Список цитированных источников}

1. Водный кодекс Республики Беларусь [Электронный ресурс] : Закон Респ. Беларусь, 30 апреля 2014 г. № 149-3 // ЭталонБеларусь / Нац. центр правовой информ. Республики Беларусь.

2. Гертман, Л. Н. Из опыта разработки проектов водоохоранных зон и прибрежных полос в соответствии с действующим 
Вестник Брестского государственного технического университета. 2021

законодательством / Л. Н. Гертман, И. Ю. Буко, А. П. Шариков // Земля Беларуси - № 1. - март 2018. - С. 45-48.

3. Гертман, Л. Н. Из опыта разработки проектов водоохоранных зон и прибрежных полос в соответствии с действующим законодательством / Л. Н. Гертман, И. Ю. Буко, А. П. Шариков // Земля Беларуси - № 2. - июнь 2018. - С. 20-23.

4. Гертман, Л. Н. Разработка каталога водоохранных территорий водных объектов Республики Беларусь / Л. Н. Гертман, П. П. Рутковский, И. Ю. Буко // Водные ресурсы и климат: материаль докладов $V$ Международного Водного Форума, Минск, 5-6 окт. 2017 г.: в 2 ч. / Белор. госуд. технолог.ун-т; редкол.: О. Б. Дормешкин [и др.] - Минск, 2017. - Ч. 1.- С. 77-82.

5. Курлович, Д. М. ГИС-картографирование земель: учеб.-метод. Пособие / Д. М. Курлович. - Минск : БГУ, 2011. - 244 с.

6. О государственной экологической экспертизе, стратегической экологической оценке и оценке воздействия на окружающую среду [Электронный ресурс] : Закон Республики Беларусь, 18 июля 2016 г. № 399-3 // Эталон-Беларусь / Нац. центр правовой информ. Респ. Беларусь.

7. О нормативных правовых актах [Электронный ресурс] : Закон Республики Беларусь, от 17 июля 2018 г. № 130-3 // ЭталонБеларусь / Нац. центр правовой информ. Респ. Беларусь.

8. О требованиях к разработке проектов водоохранных зон и прибрежных полос [Электронный ресурс]: постановление Министерства природных ресурсов и охраны окружающей среды Республики Беларусь, 04 мая 2015 г., № 18 (с изменениями от 17.03.2017 № 9). // Право Беларуси. - Режим доступа: http://www.lawbelarus.com/005048. - Дата доступа: 09.01.2019.

9. Об утверждении Правил благоустройства и содержания населенных пунктов [Электронный ресурс] : постановление Совета Министров Республики Беларусь, от 28.11.2012 № 1087 // ЭталонБеларусь / Нац. центр правовой информ. Республики Беларусь.

10. РУП «Центральный научно-исследовательский институт комплексного использования водных ресурсов» [Электронный ресурc]. - Режим доступа: http://www.cricuwr.by.

11. ЭкоНиП 17.01.06-001-2017 Требования экологической безопасности [Электронный ресурс] : постановление Министерства природных ресурсов и охраны окружающей среды Республики Беларусь, от 18 июля 2017 № 5-Т // Эталон-Беларусь / Нац. центр правовой информ. Республики Беларусь.

\section{References}

1. Vodnyj kodeks Respubliki Belarus' [Elektronnyj resurs] : Zakon Resp. Belarus', 30 aprelya 2014 g. № 149-Z // Etalon-Belarus' / Nac. centr pravovoj inform. Respubliki Belarus'.
2. Gertman, L. N. Iz opyta razrabotki proektov vodoohorannyh zon i pribrezhnyh polos $v$ sootvetstvii s dejstvuyushchim zakonodatel'stvom / L. N. Gertman, I. YU. Buko, A. P. SHarikov // Zemlya Belarusi - № 1. mart 2018. - S. 45-48.

3. Gertman, L. N. Iz opyta razrabotki proektov vodoohorannyh zon i pribrezhnyh polos v sootvetstvii s dejstvuyushchim zakonodatel'stvom / L. N. Gertman, I. YU. Buko, A. P. SHarikov // Zemlya Belarusi - № 2. iyun' 2018. - S. 20-23.

4. Gertman, L. N. Razrabotka kataloga vodoohrannyh territorij vodnyh ob"ektov Respubliki Belarus' / L. N. Gertman, P. P. Rutkovskij, I. YU. Buko // Vodnye resursy i klimat: materialy dokladov V Mezhdunarodnogo Vodnogo Foruma, Minsk, 5-6 okt. 2017 g.: v 2 ch. / Belor. gosud. tekhnolog.un-t; redkol.: O. B. Dormeshkin [i dr.] - Minsk, 2017. - CH. 1.- S. 77-82.

5. Kurlovich, D. M. GIS-kartografirovanie zemel': ucheb.-metod. Posobie / D. M. Kurlovich. - Minsk : BGU, 2011. - $244 \mathrm{~s}$.

6. O gosudarstvennoj ekologicheskoj ekspertize, strategicheskoj ekologicheskoj ocenke i ocenke vozdejstviya na okruzhayushchuyu sredu [Elektronnyj resurs] : Zakon Resp. Belarus', 18 iyulya 2016 g. № 399-Z II Etalon-Belarus' / Nac. centr pravovoj in-form. Respubliki Belarus'.

7. O normativnyh pravovyh aktah [Elektronnyj resurs] : Zakon Resp. Belarus', ot 17 iyulya 2018 g. № 130-Z // Etalon-Belarus' / Nac. centr pravovoj inform. Respubliki Belarus'.

8. O trebovaniyah $\mathrm{k}$ razrabotke proektov vodoohrannyh zon i pribrezhnyh polos [Elektronnyj resurs]: postanovlenie Ministerstva prirodnyh resursov i ohrany okruzhayushchej sredy Respubliki Belarus', 04 maya 2015 g., № 18 (s izmeneniyami ot 17.03.2017 № 9). // Pravo Belarusi. - Rezhim dostupa: http://www.lawbelarus.com/005048. - Data dostupa: 09.01.2019.

9. Ob utverzhdenii Pravil blagoustrojstva i soderzhaniya nase-lennyh punktov [Elektronnyj resurs] : postanovlenie Soveta Ministrov Resp. Belarus', ot 28.11.2012 № 1087 // Etalon-Belarus' / Nac. centr pravovoj inform. Respubliki Belarus'.

10. RUP «Central'nyj nauchno-issledoาvatel'skij institut kom-pleksnogo ispol'zovaniya vodnyh resursov» [Elektronnyj re-surs]. - Rezhim dostupa: http://www.cricuwr.by.

11. EkoNiP 17.01.06-001-2017 Trebovaniya ekologicheskoj bezopasnosti [Elektronnyj resurs] : postanovlenie Ministerstva prirodnyh resursov i ohrany okruzhayushchej sredy Respubliki Belarus', ot 18 iyulya 2017 № 5-T // Etalon-Belarus' / Nac. centr pravovoj inform. Respubliki Belarus'.

Материал поступил в редакцию 02.03.2021 